\title{
TERRITORIAL PLANNING AND TOURISM IN THE RURAL JOINVILLE-SC
}

\author{
Marinês da Conceição Walkowski \\ Mirtz Orige Oliveira \\ Vinicius Boneli Vieira \\ Carlos Loch
}

p. $01-24$

Como citar este artigo:

WALKOWSKI, M. C.,Mirtz Orige Oliveira, Vinicius Boneli Vieira, Carlos Loch. TERRITORIAL PLANNING AND TOURISM IN T HE RURAL

JOINVILLE-SC. Eletronic Magazine: Time - Techinique - Territorry, v.5, n.1 (2014), p. 1:22 ISSN: 2177-4366.

revista

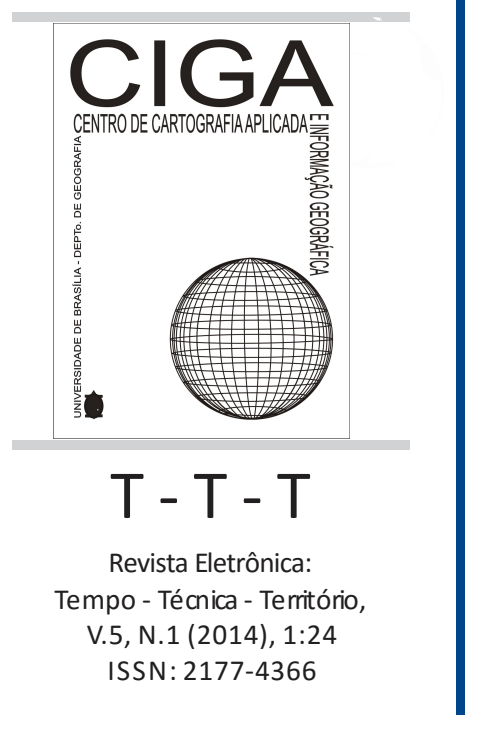

DOI: https://doi.org/10.26512/ciga.v5i1.22175

Disponível em: http://periodicos.unb.br/index.php/ciga/

Este obra está licenciado com uma Licença Crea tive Commons

Atribuição-NãoComer cial 4.0 Inter nacional.

DOI: https://

doi.org/10.26512/

ciga.v5i1.22175 


\title{
TERRITORIAL PLANNING AND TOURISM IN THE RURAL JOINVILLE-SC
}

\author{
Marinês da Conceição Walkowski \\ Bacharel em Turismo, Doutorado em Arquitetura e Urbanismo pela Universidade de \\ Santa Catarina, Brasil (2013). \\ E-mail: \\ marinesw@yahoo.com.br
}

\begin{abstract}
Mirtz Orige Oliveira
Arquiteta, Doutoranda em Engenharia Civil pela Universidade de Santa Catarina, Brasil (2013).

E-mail:

Mirtz.orige@posgrad.ufsc.br

Vinicius Boneli Vieira

Bacharel em Turismo, Mestre em Geografia pela Universidade Federal do Paraná, Brasil

E-mail: viniciusbonelli@gmail.com

\author{
Carlos Loch \\ Professor, Dr. Departamento de Engenharia Civil pela Universidade de Santa Catarina, \\ Brasil. \\ E-mail: \\ loch@ecv.ufsc.br
}

\begin{abstract}
The rural southern Brazil shows potential for tourism due to the significant scenic beauty, cultural riches and land structure based on small family farms whose economic viability of the activities demand variation so pluriativa. However, for this potential can be tapped is a need for systematic information and spatialized that allow the user to access and enjoy the rural destinations and equipment. In this direction lies the challenge for territorial planning, using GIS data when making decisions, seek the strengthening of Joinville city as tourist hub in its region. In this context, the objective of this research is to characterize physically and spatially Pirai River watershed, using Multipurpose Technical Cadastre (CTM) and Geographic Information System (GIS) for geoprocessar, fotointerpretar and analyze data from the refund aerophotogrammetric 2010, to support tourism planning in a sample area of rural de Joinville. The methods used were GIS vector data and tabular fotointepretação aerial imagery and physical-spatial analysis, with the CTM and GIS tools, which were presented in ArcGis 10. The results were obtained thematic maps of 3 properties with tourism-related production. It was concluded that the results indicated that the CTM, the potential of GIS and high resolution images are essential for tourism planning in the preparation of maps to publicizing the local tourist product and diagnosis of 3 properties with tourismrelated production.
\end{abstract}


Keywords: Rural Tourism, Territorial Planning; Multipurpose Technical Cadastre; Geographic Information Systems; Joinville.

RESUMEN: La población rural del sur de Brasil muestra potencial turístico debido a la belleza escénica significativa, la riqueza cultural y la estructura de la tierra basada en las pequeñas explotaciones familiares cuya viabilidad económica de la variación de la demanda de actividades para pluriativa. Sin embargo, para que este potencial puede ser aprovechado es necesario contar con información sistemática y espacializado que permiten al usuario acceder y disfrutar de los destinos rurales y equipos. En esta dirección se encuentra el desafío de la planificación territorial, a partir de datos de SIG hora de tomar decisiones, buscar el fortalecimiento de la ciudad de Joinville como centro turístico en la región. En este contexto, el objetivo de esta investigación es caracterizar física y espacialmente cuenca del río Piraí, el uso polivalente Catastro Técnico (CTM) y el Sistema de Información Geográfica (SIG) para geoprocessar, fotointerpretar y analizar los datos de la devolución Aerofotogramétrico 2010, para apoyar la planificación del turismo en un área de muestra de las zonas rurales de Joinville. Los métodos utilizados fueron SIG vectorial y tabular los datos fotointepretação imágenes aéreas y análisis físicoespacial, con la CTM y herramientas SIG, que se presentaron en ArcGIS 10. Los resultados se obtuvieron mapas temáticos de 3 propiedades con la producción relacionada con el turismo. Se concluyó que los resultados indicaron que el CTM, el potencial de los SIG e imágenes de alta resolución son esenciales para la planificación del turismo en la elaboración de mapas de dar a conocer el producto turístico local y diagnóstico de 3 propiedades con la producción relacionada con el turismo.

Palabras clave: Turismo Rural, Planificación Territorial, Catastro Técnico Polivalente, Sistemas de Información Geográfica; Joinville.

\section{INTRODUCTION}

The evolution of society was related to the actual evolution of the territory, according to the local productive vocations, fruit, in many cases, a planning process.

The plan comes as a new paradigm for the development of a tourist destination, and can assist managers in decision-making in land management.

The territory can be understood as a socially organized space where there are exchange relationships can the same, being in social, economic and institutional.

For this reason, planning must be founded on the recognition of the territory and its complexity on social interactions, environmental, political and economic, assisting in the management, structuring and proposing projects to minimize impacts and seek development site.

In relation to tourism, can be seen as a multidisciplinary activity that requires a range of information and involves various areas of knowledge such as architecture and urbanism, geography, economics, management, among others. For proper planning of this activity requires investment in quality information, for example, the existence of 
adequate infrastructure, location, signaling potential of natural and cultural heritage and the involvement of local actors. Accordingly, the information should be analyzed and systematized, taking into account the objective and subjective elements within the territory and that will subsidize the decision support in planning.

Currently, there are experiences of tourism in rural areas, which have contributed to the development in the world, however, based on the existing literature, there are few effective tools for measuring the effects generated within the territory due to these experiences. There is also no clear parameters that same scenario in other countries, depending on the physical and geographical characteristics that mostly are geographic areas lower than Brazil and its potential landscape.

Given the above, the objective of this research is to characterize physically and spatially Pirai River watershed, and using GIS for CTM geoprocessar, fotointerpretar and analyze data from the refund aerophotogrammetric 2010, to support the planning of tourism in an area of the sample space rural Joinville.

\section{TERRITORIAL PLANNING AND TOURISM}

The notion of territory becomes wide will measure that includes a number of other dimensions, including the elements that make up the landscape and spatial planning as a tool for these relationships. The concept of territory comes at the end of the 1980s, with bases in political geography, as the concrete space itself, with its natural attributes and socially constructed, suitable, occupied by a social group. According to Castro (2003), the territory is understood as a space defined and delimited from power relations.

Territorialization as Claval (1999), can also be considered as one of the essential ingredients of different identities, not presenting the same ability to reproduce and or the same way, they are ranked and can be fragmented.

Thus, the territory has not only compared with the traditional political power, but with more explicit power, domination and power in a symbolic sense, the appropriation. According Haesbaert (2007), the appropriation is highlighted as a symbolic process due to the fact carry marks of "lived", the value in use. Already domination is represented by a functional process linked to the exchange value. 
The territories are constructed and deconstructed in various scales, ie a concrete space itself with its attributes (natural, architectural heritage and landscape) that is appropriate, occupied by a social group, capable of generating socio-cultural roots and identity (Corrêa et al, 1995).

In this context, Pecqueur (1992) space-territory has a strong influence on the development, rather than just a support apparent and becomes an element of productive organization that will influence the strategies of individual actors and firms. In this sense, the material point of view and productive territories may assume the character of local productive systems, also known as millieux or atmospheres that territorializam the place in which proceeds a plurality of forms of justification of human action (reciprocity, cooperation, competition, contest, etc). The territory goes beyond the economic dimension and material is the result of the relationship between social groups.

The territorial logic is to build and strengthen interdependencies between economic sectors and between the political, social and spatial. Therefore, the establishment of networks of institutions have a direct correlation to the structure and quality of existing services, beyond ownership through social representations (CAZZELLA, 2007; RODRIGUES, 2006).

Still, the formation of a territory generates in people that inhabit the consciousness of their participation, provoking a sense of territoriality, creating a sense of brotherhood among all (ANDRADE, 1995). From the geographical point of view, a territory can also be set from the productive activities on the basis of proximity relations among economic actors, which can generate a synergistic effect, creating a comparative advantage in relation to the outside (MILK, P., Bonnal, CAZZELLA, DELGADO, 2011).

Planning is a tool that provides necessary support to the structuring of any activity, minimizing potential problems and managing future actions. Can be broadly defined as a process of rationalization, referring to any kind of action by which the government and other bodies, through a political-ideological, identify objectives to be achieved in a given area and defines the means for achieving. It therefore sets out a program of action that are integrated and coordinated all possible actions, account the desires, goals, 
worldviews of social actors that drive and must be continuous (Cruz, 2006; Espadafor et al, 2010).

Hail (2005) mentions that the territory planning should cover the needs of space, the natural constraints (involving relief, climate, river flows, tides, etc..) And include human behavior (economic and social considerations).

Territorial planning aims to promote and foster spatial functions, movement and deployment of infrastructure and urban facilities, in order to maximize the production of economic activities, focused on the evaluation and planning of land use and management of natural resources, regional level, in order to preserve and restore the ecological balance and protect the environment (BENI, 2006; PIRES et al, 2009).

In this respect especially the circulation and consumption of space, have been increasingly frequent by tourists and locals. This phenomenon has attracted researchers in the area of tourism and different interest analysis, especially regarding the use of these spaces, seen as a necessity of society in pursuit of the enjoyment of their free time, as well as a closer relationship of humans with the natural environment. The valuation of rural areas has favored in the process of planning and management of these spaces, directing public policy and providing opportunities for financial sustainability and promoting research in these areas.

According to Pires (2009), the development of tourism depends on factors which should be observed in a systematic way, as these elements are interrelated, interdependent and develop a dynamic and integrated.

The study of the spatial dimensions of tourism has reflected many analyzes as researchers: Coriolanus (2007) Carlos (1996), Cross (2007), Rodrigues (1996, 1999), Xavier (2007) that identify the dynamics and complexity of the tourism phenomenon as an agent of transformation and territorial organization.

To the World Tourism Organization (2003, p. 20), tourism comprises "the activities of persons traveling to places away from their usual environment, or to remain in them for less than one consecutive year for leisure, business or a other reasons ". 
According Coriolanus (2009), tourism can also be understood as one of the key activities of contemporary modernization that emphasizes relationships socias typical consumer society to transform leisure into a commodity to be consumed on trips, assuming other outlets. In this society the socio-spatial organization is a result of the imposition of modern way of life that prioritizes the needs of capital contradictory process that weakens the state, but strengthens social movements and democracy, expands exclusion and poverty as it may broaden the participation.

Therefore, the activities of productive centers of tourism have resulted in this dynamic, representing survival strategies based on human creativity, use of technology by human labor to satisfy material needs, is influenced market laws. In the restructuring of the economic crises industrial services stand out among the current economic activities, giving due emphasis on tourism.

In constant transformation of tourism, especially regarding the needs and desires of the human being, there is a global trend as the fruition of different environments of large urban centers, such as rural areas, which make it possible to cure the ills of modern life and refer to the natural state of being, expanding their perceptions and sensitivities.

Tourism has different characteristics according to each partner configuration space, influenced by the environment in which it is inserted and in rural areas may also occur a number of tourist practices. The rural tourism, rural tourism or simply, are all endogenous tourism activities developed in the natural environment and human (ZIMMERMANN, 2003; PORTUGUEZ, 2002).

The rural tourism is an activity that involves aspects: social, political, cultural and especially economic appearing on the world stage as a strong driving force for sustainable development in environmental preservation. Therefore, knowledge of the complex reality of this activity in rural areas in its multiple dimensions and dynamically becomes imperative to manage them efficiently

\section{GEOGRAPHIC INFORMATION SYSTEMS AND MULTIPURPOSE TECHNICAL CADASTRE}


Knowledge of information about the wealth of the municipality in Joinville, is important in recognizing the tourism potential.

One of the tools that assist in identifying tourism potential is the use of aerial images. The images are found relevant data such as the slope, vegetation type, soil type, hydrology, among others.

Another key tool is the Geographic Information System (GIS) that can be defined more broadly as a set of programs, equipment, methodologies, data and people (users), perfectly integrated in order to make it possible to collect, storage, analysis and processing of georeferenced data, besides the production of information derived from their application (MATIAS, 1996).

The technology favored the creation of GIS as a function of speed and the ability to interact with different areas. In this sense, GIS is fundamental in the construction of a Decision Support System for Tourism.

The concept of Decision Support System may vary depending on different areas of knowledge. Means a system as a set of interdependent elements or organized as a whole or parts comprising forming a unitary whole and complex, and can be closed (machines, watches) or open system (biological and social) (BIO 2008).

Many information systems are underutilized tourism, working only in the operational sphere, such as databases, without further interactions provide only values such as number of attractive data, location and contacts. Thus, these systems lack interactivity and neither do the processing required to assist managers in tourism decision making.

The creation and use of geographic information systems allow management of space tourism, through the intersection of information, such as: the distribution of the attractions for the various equipment (room and board), the access to the attractions and equipment, infrastructure tourism and support and spatial mapping of the main poles emitting tourists and their paths to the tourist spot and demand characterization of each attraction, thus allowing the manager of tourism, identify imbalances between supply and demand, intervening through strategies and actions (DUKE; MENDES, 2006). 
The intersection of this information, systematized through GIS are the basis of a register, indispensable to the planning of any tourist destination.

The planning process can be considered as a multidisciplinary activity, and should add various fields. The term multipurpose justified by meeting various users and purposes (LOCH; KIRCHNER, 1988). However, proper planning should be guided by a source of reliable and adequate information about the local reality.

The records related to the implementation of multifunctional projects administrative and fiscal policy plays a key role in territorial planning, as it provides geographic information for more detail on aspects of the territory and the environment. It is an administrative record by mapping that generates a registration database composed of interrelated information (Espadafor et al, 2010).

In this sense, the Technical Registry, along with the Information System of the territory become an indispensable element in the dissemination of tourist destinations. The complexity of the tourism phenomenon requires "recognition space, coordinating projects and promoting actions that strengthen the process of developing a particular locality" (RECH, 2009, p. 165).

The tools mentioned above will provide necessary support to the structuring of activity and tourism management from the point of view of local development.

Rural areas lack information in several areas. In tourism, the information is insufficient, incomplete and / or generic, and does not, in many cases, an analysis of the existing tourism potential. The systematization of information, through a Multipurpose Technical Cadastre will support decision-making and assist in the planning of rural.

\section{DESCRIPTION OF THE STUDY AREA AND POTENTIAL FOR TOURISM}

The city of Joinville, located to the northeast of the state of Santa Catarina. It is considered a major center for business and events in the face of significant industrial activity, which has attracted many visitors. 


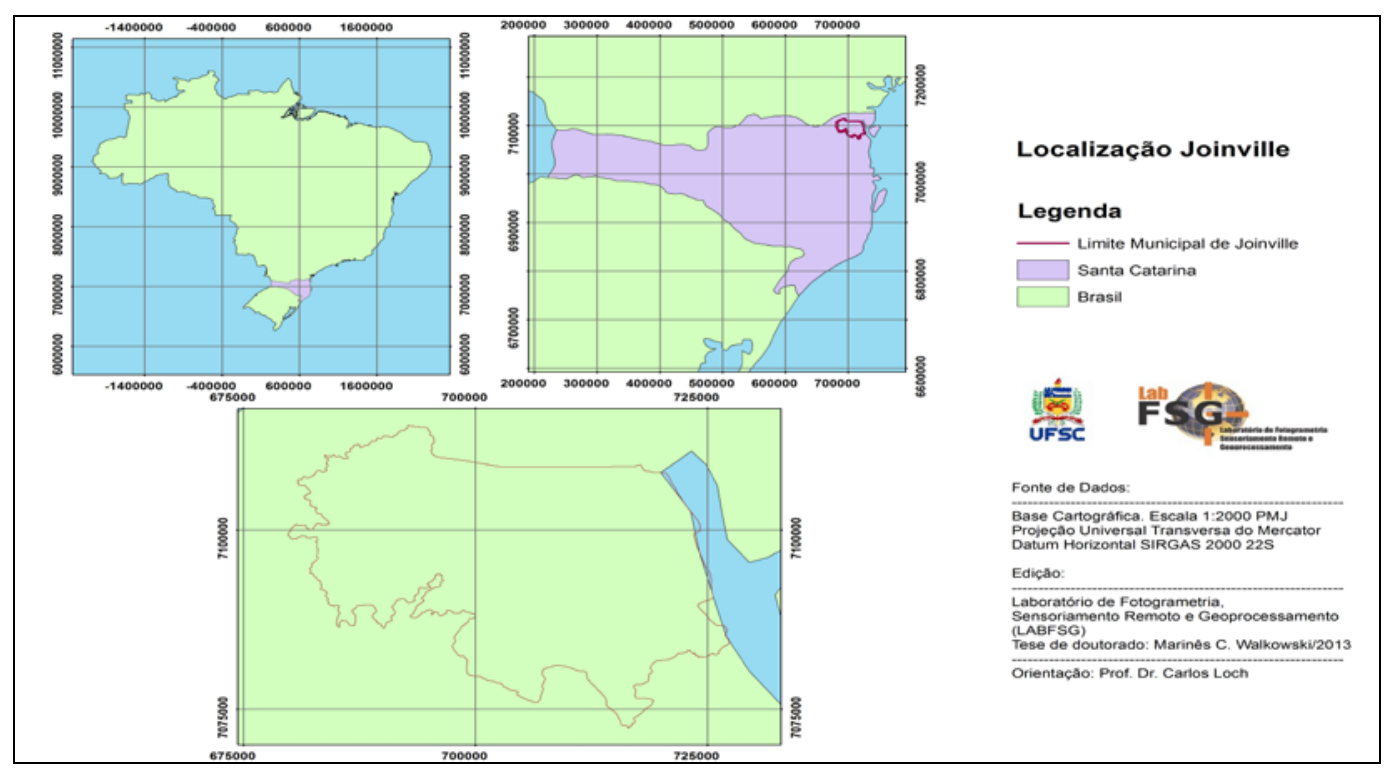

Figura 1. Localização de Joinville.

Elaborado com base na PMJ (2012) e IBGE (2008).

The municipality has an area of $1126.03 \mathrm{~km}^{2}$, colonized by European immigrants on March 9, 1851. It is considered the largest city in the state with a population of 515,288 inhabitants (IBGE, 2010), accounting for 20\% of exports and the 3rd industrial hub of the southern region. The main access is by BR101, one of the main access roads to the south of the country. Distant $180 \mathrm{~km}$ from the capital of Santa Catarina Florianópolis south and 120 kilometers from the state capital Curitiba north.

The climate is humid to super humid. The relief develops on land the Serra do Mar and an area of coastal sedimentation. For vegetation, characterized by the Atlantic and Mangroves. More than 60\% (680km $\left.{ }^{2}\right)$ Rain Forest and $36 \mathrm{~km}^{2}$ of mangroves (IPPUJ, 2009).

In a radius of $100 \mathrm{~km}$ is possible to find mountain landscapes (Campo Alegre, Sao Bento do Sul) or praianas (South San Francisco, South Bar, among others), these features enable an integrated work in the region, both disclosure, as routing (PLAN tO STRENGTHEN PUBLIC MANAGEMENT oF TOURISM, 2008).

The city stands out for the Environmental Protection Area of Serra da Dona Francisca, whose goal is the protection of water resources integrated into the region's economic 
development and has an area of $408.42 \mathrm{~km}^{2}$, covering the springs and rivers Cubatão Pirai - the main sources of supply of the municipality. Even within this protected area has also three other units: Rolf Colin Park, PRNP Caetezal and Ecological Station Bracinho. These units only APA and PRNP Caetezal have management plans completed which also include tourist activities (ENGECORPS, 2010).

In relation to hydrography, the city stands out for great potential in water resources, caused by heavy rains and the dense forest cover remaining. The hydrographic system is organized predominantly in the Atlantic slope of the Serra do Mar, whose rivers are characterized by having small extension and a great flow. The city has a large hydro potential, provided by the combination of periodic rains with good preservation of the remaining forest cover. The spatial hydrographic consists of seven units of planning and management of water resources, which are: River Basin Palmital River Basin Cubatão North Pirai River Basin, River Basin Itapocuzinho, River Basin Waterfall , Watershed of East Strand and Watershed Independent Strand South (IPPUJ, 2009).A área rural possui $912.422 \mathrm{~km}^{2}$ onde há aproximadamente 17.462 famílias, representando 3,4\% da população de Joinville (IBGE, 2010).

The rural environment is represented by family farms, where $97 \%$ of farms have less than 50 hectares and production ranges from the cultivation of rice, bananas and vegetables, present in an area of 89.549ha divided into crops, reforestation, pasture and forests. In addition, there is also a highlight for pscicultura, fishing, beekeeping and agro-industries. Another activity that has developed in rural areas is rural tourism with emphasis on the following tourist areas: Bonita Road, Pirai, Quiriri, Dona Francisca (with the rural roads of the Peak, Silver, Izaack, River of Julius and Mildau) and recently the Island Highway that is still being diagnosed (IPPUJ, 2009).

In rural areas, there is still a highlight for cycling projects and tourism teaching that has allowed, adults, youth and children in the city and region experiencing the habits and customs of the countryside and has generated a significant flow of visitors throughout the year on the property. Being crucial in this regard emphasize the potential in rural areas. 
The ecotourism, adventure tourism and cultural tourism are also segments developed within and around the APA Serra Dona Francisca, but can still be considered activities not so significant from the point of view of tourist flow. Ecotourism, as well as adventure tourism, are operated by only one company that offers packages for trekking activities allied to practical environmental education and contemplation of nature in the mountains of the municipality and region. The segment of cultural tourism, despite having a small flow of tourists, is also inserted in the packages offered by receptive agencies, which mixes with the experiences of rural tourism and agrotourism.

For this research, is being used a pilot sample, consisting of 3 properties with associated production to tourism, located in the watershed of the river Pirai.

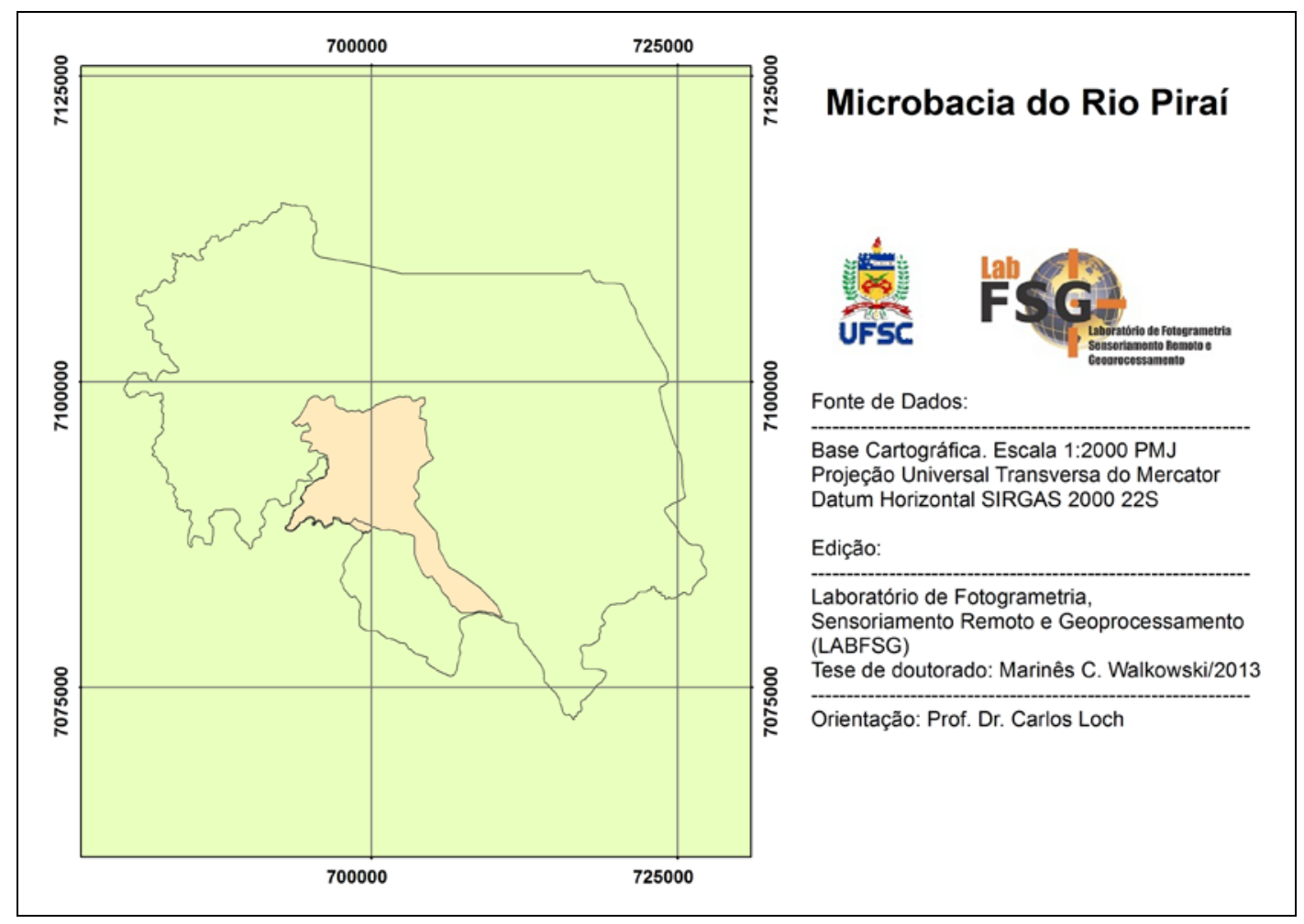

Figura 2. Localização da microbacia rio Piraí.

Elaborado com base na PMJ (2012) e IBGE (2008).

The watershed of the river Pirai focus of this research is to the west of the city, $10 \mathrm{~km}$ far from the center of Joinville. Rural tourism Pirai includes road, amid the natural beauty of its places, stands out for the marketing of regional products: breads, cookies, jams, cheeses, cakes and also the craftsmanship. In the script, parks, rivers and 
waterfalls celebrate the connection between man and nature. Some projects work the Adventure Tourism, Ecotourism and Environmental Education. The Pirai River watershed has an area of $\mathrm{km}^{2} 114.369 .91$ which has $12.53 \%$ of the rural area of Joinville and there are 372 properties found in agrarian structure, which represent $10 \%$ of existing properties in the rural area (IPUJJ, 2011).

The choice of the area of research is justified because it is the first town to develop tourism in the city of Joinville and possess properties that already work in tourism in different segments focusing on agricultural production, craft, and the natural beauty.

\section{METHOD AND MATERIALS}

We conducted a cooperation agreement between the City of Joinville and the Laboratory of Photogrammetry, Remote Sensing and GIS (LabFSG / UFSC), which subsidizes different theses and dissertations in the municipality. This agreement allowed access to digital files in shapefile format. Among these, is the foundational structure that it is a preliminary version, since it was not validated by the registry of the farm and also the digital files in shapefile format of the sights that make up the Pirai River watershed.

The materials used were obtained from the Municipal Information System Georreferrenciadas (SIMGEO) Joinville and refer to restitution aerophotogrammetric 2010 (Base cartographic scale 1: 5000 and 2010 aerial photographs at scale 1: 20,000) and digital files in shapefile format of sights of the watershed in question. Files in shapefile format limits the watershed were extracted Information System georeferenced EPAGRI (SIGEO).

The methods used are included in GIS vector data, photo-interpretation of aerial imagery and physical-spatial analysis.

The GIS vector data came from a preliminary stage which was the processing of data from the charts of the refund aerophotogrammetric 2010 in order to facilitate the preparation of graphics products. In the definition of the letters of the sampling area, were identified which are the letters in SIMGEO-PMJ covering the limits of the watershed and were acquired and articulated in CAD, with the original coordinate system. For creating digital files of type shapefile extracted in GIS vector data of the 
following layers: contours, hydrology, lakes and rivers, vegetation, highways and roads, land tenure.

For the clipping of vector data and aerial photographs was used limits the watershed acquired in digital format in shapefile format SIGEO-EPAGRI.

The physical-spatial analysis consisted primarily in the description of the basic attributes: sample area, representativeness of thier total area rural.

For the preparation of thematic maps was made the crossing of the agrarian structure with points made available by the Foundation Tourist Joinville - PROMOTUR, properties with tourism-related production.

\section{RESULTS AND DISCUSSION}

The results are included in the data processing and product generation graphics executed in step GIS vector data in image interpretation and analysis of aerial images and physical space. The discussion is then presented of the results of each methodological procedure performed.

In GIS Data were developed digital files of type shapefile for each layer that were spatially containing basic information regardless of physical-spatial Pirai River watershed (Figure 3). 


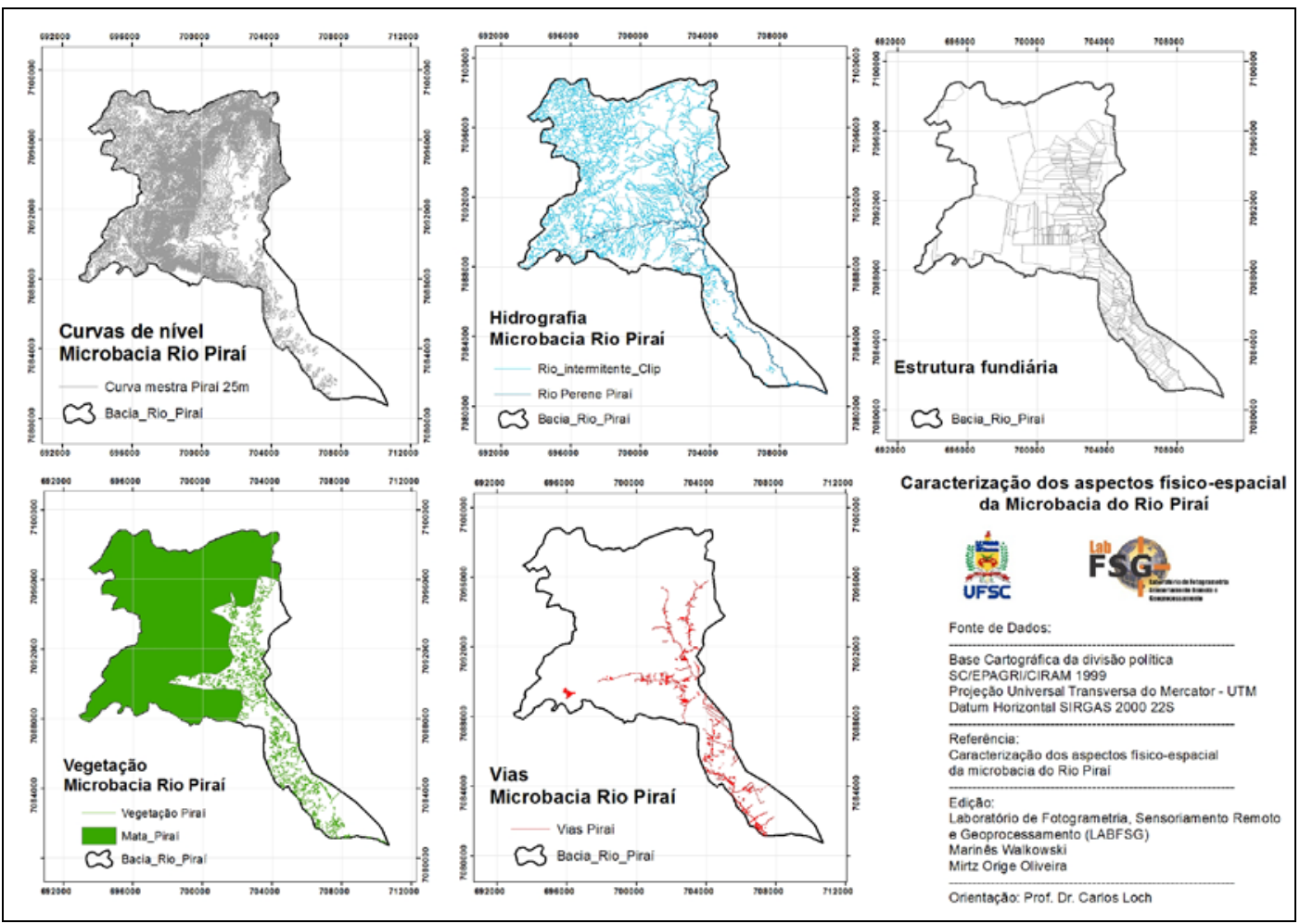

Figura 3. Caracterização físico-espacial da microbacia rio Piraí. Elaborado com base na PMJ (2012) e SIMGEO (2013).

The physical-spatial analysis allowed the observation of the physical in terms of natural beauty and their spatial locations in the watershed and then the properties with tourismrelated production.

In relation to the contour lines are observed steeper slopes and slopes that point to the potential development of nature tourism activities and adventure - hiking and nature walks and environmental education.

With respect to vegetation, were observed several remnants of Atlantic forest still preserved.

The hydrographic system is organized predominantly in the Atlantic slope of the Serra do Mar, whose rivers are characterized - by presenting small extension and a great flow. The city has a large hydro potential, provided by the combination of periodic rains. 
The photo-interpretation of aerial images also preceded a preliminary stage, which consisted of two methodological procedures, limiting itself to the contours of the Pirai River watershed, which are: i) assembling the mosaic and ii) cut mosaic composed of 2010 digital images (Fig. 4 and 5).

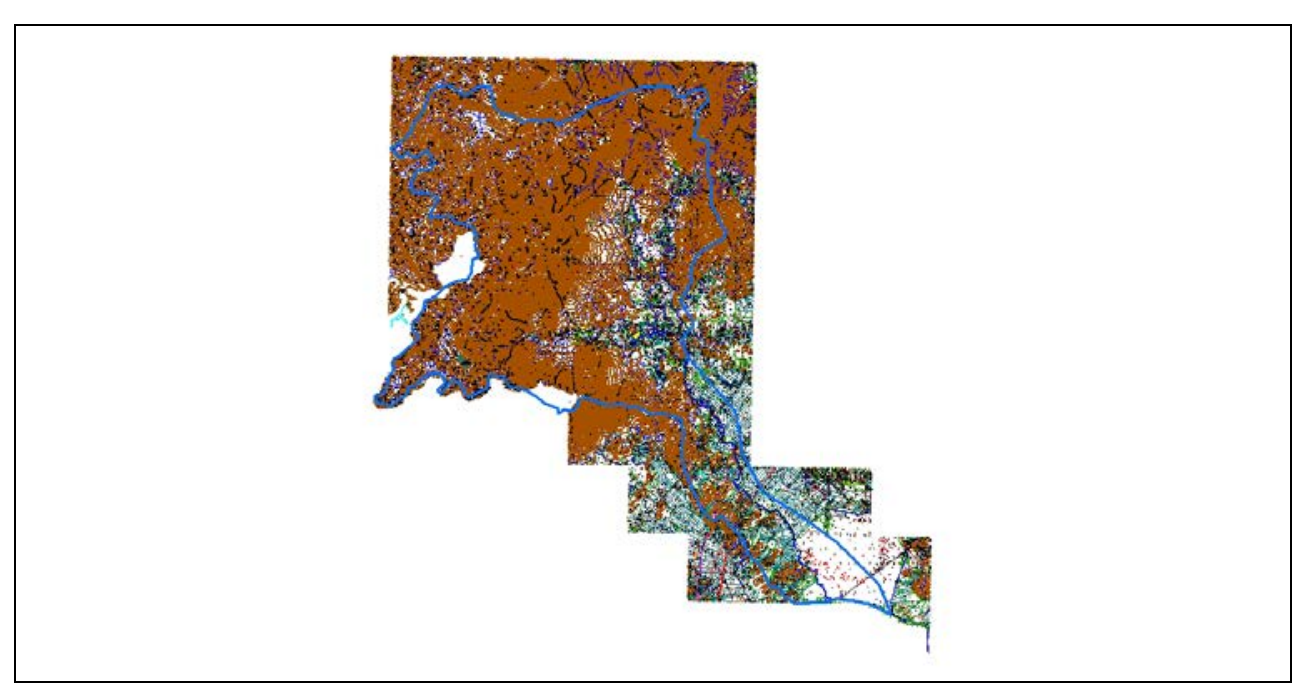

Figura 4. Montagem do mosaico da microbacia rio Piraí. Elaborado com base na PMJ (2012) e SIMGEO (2013).

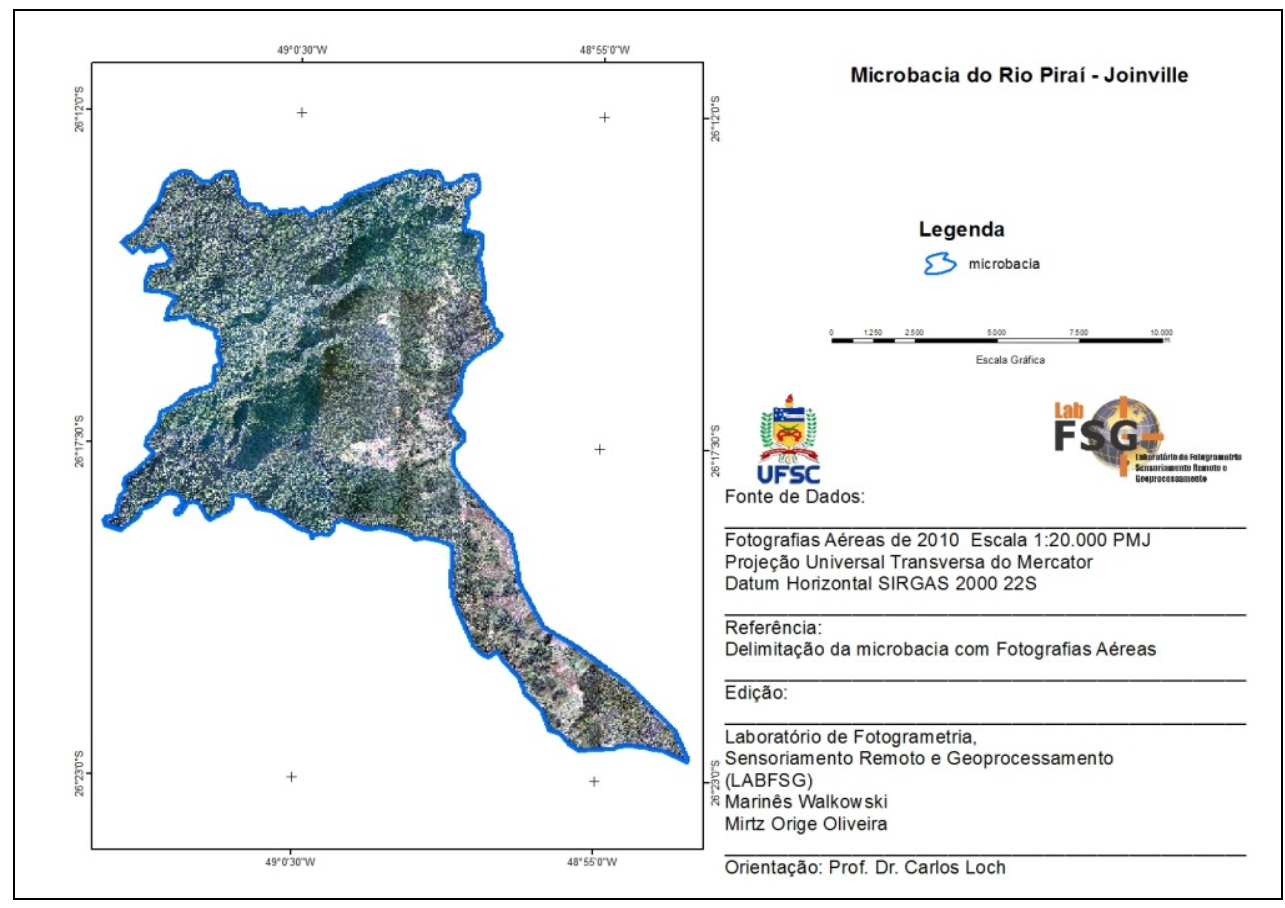

Figura 5. Contorno da microbacia rio Piraí. Elaborado com base na PMJ (2012) e SIMGEO (2013). 
In sequence held overlapping vector data found in the preliminary stage of the GIS in images, with emphasis on a set of images consisting of properties with tourism-related production (Figure 6).

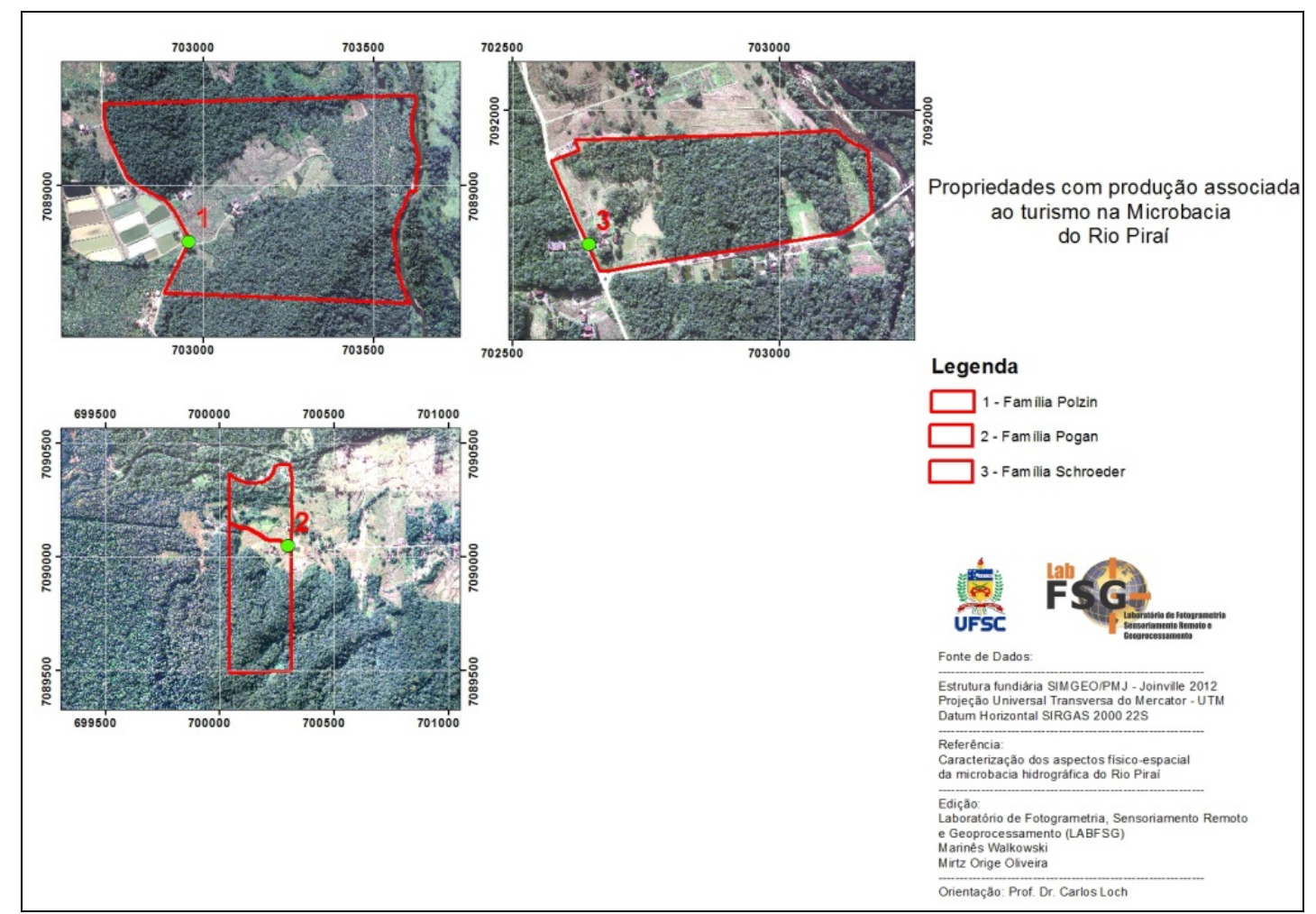

Figura 6. Amostra da pesquisa - propriedades com produção associadas ao turismo na microbacia do rio Piraí.

Elaborado com base na PMJ (2012) e SIMGEO (2013).

After this step was generated a representative sample of properties with tourism-related production (Figures 7, 8 and 9).

Properties with tourism-related production in the Pirai River watershed are characterized by scenic beauty and diversity of potential existing in various cultures that are expressed by the production of handicrafts, agricultural production, fish farming, beekeeping, and by the natural and cultural heritage. However, for this study, we used only a sample of this potential, comprising three properties. 
Observe that this tourism activity in this watershed and helps to generate additional income, the promotion and enhancement of the local product improving their quality and encouraging the permanence of these farming families in the countryside.

Were identified, registered and located geographically the following properties: 1. Polzin Family 2. Pogan family, and 3. Schroeder family.

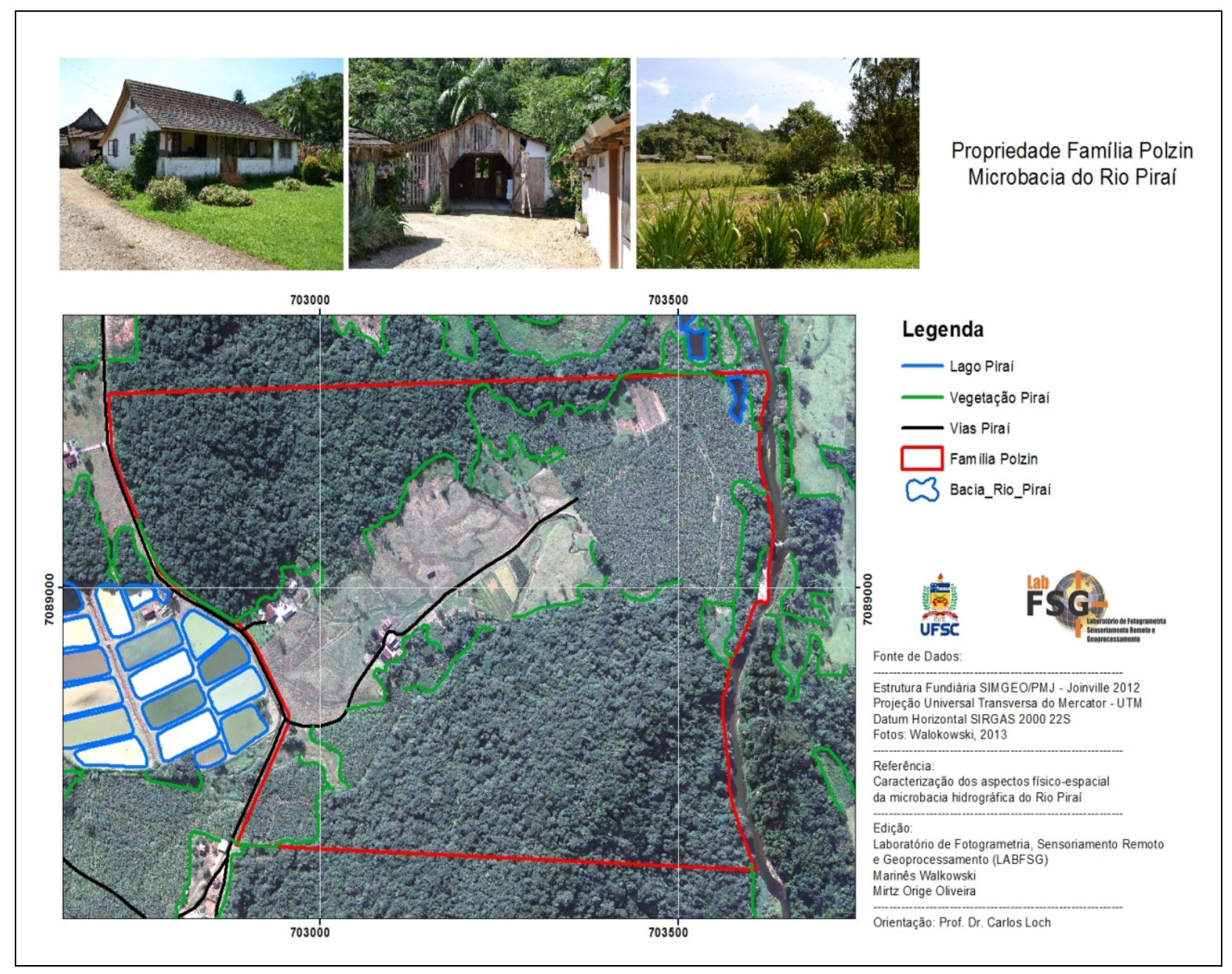

Figura 7. Propriedade Família Polzin - da microbacia rio Piraí. Elaborado com base na PMJ (2012) e SIMGEO (2013). 


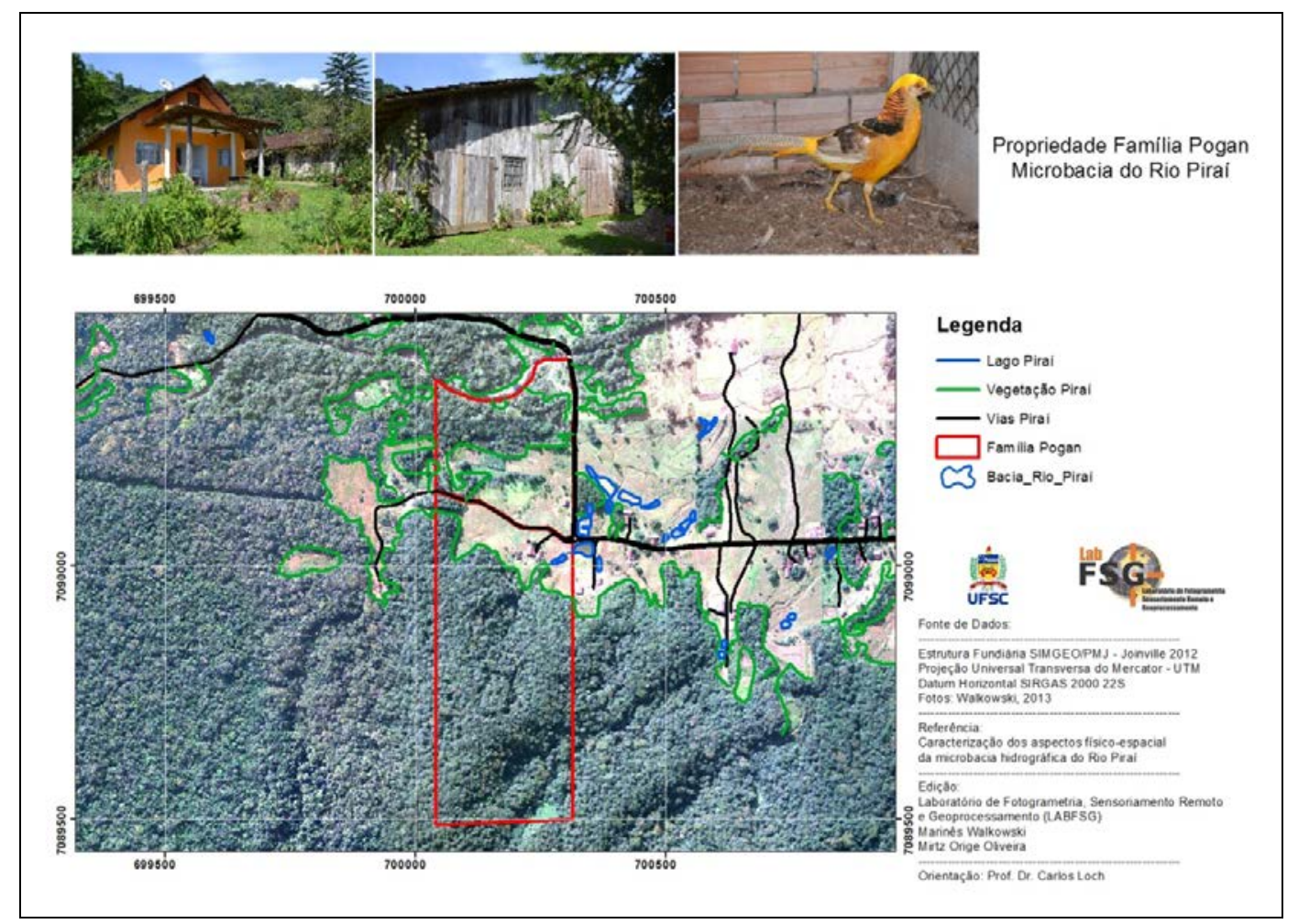

Figura 8. Propriedade Família Pogan - da microbacia rio Piraí. Elaborado com base na PMJ (2012) e SIMGEO (2013).

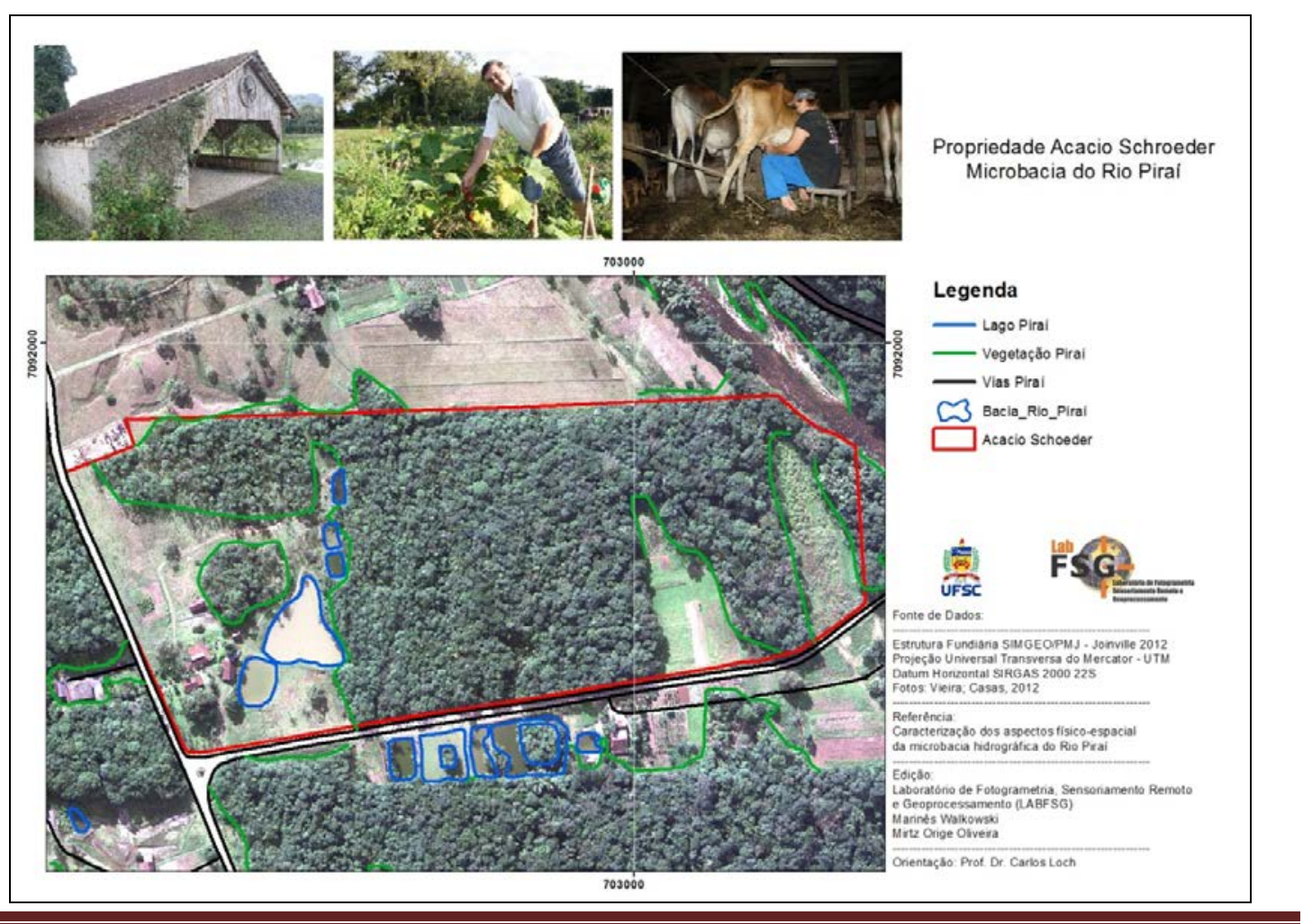

Eletronic Magazine: Time - Techinique - Territorry, V.5, N.1 (2014), 1:24 ISSN: 2177-4366 
Figura 9. Propriedade Acacio Schoeder - da microbacia rio Piraí. Elaborado com base na PMJ (2012) e SIMGEO (2013).

Farming families are highlighted by the development of its retail colonial products, organic production and colonial power.

These families are characterized by family farms and develop tourism as an income supplement. Visits are scheduled and monitoring is performed by a qualified extension. However, both properties need investment in infrastructure and organization of the surroundings.

The family property Polzin, located on Highway Serrinha post 21, offers the visitor colonial products like jams, breads, cakes, sale of ornamental plants and coffee colonial subject.

The family property Pogan, is located on the road I jump, pole 46, which are sold colonial products such as cheese and exotic birds of different species. The site also receives tourists who practice cycling and offers power subject.

Schroeder on the family property, located on the road of Morros number 1600, visitation activities are developed for the production of organic vegetables and vegetable garden. Also offered are breakfast colonial subject. The site has a shed with ample space for events such as lunch, with bathrooms and kitchen. Alongside is a lake for fishing. The property is also inserted into the script cycling and receives children from local schools to experience agricultural activities.

\section{FINAL THOUGHTS}

The knowledge and the creation of a database, through the geoprocessing tool, with detailed information on each attraction and service of local characteristics is essential to ensure support of technical knowledge through planned actions, able to promote the preservation of the environment . Thus, it is concluded that it is possible to obtain information graphic, descriptive and tabular rural, containing all the elements georeferenced to build detailed knowledge of the tourism potential. Furthermore, it is possible to organize information in order to expand the proposed activities. 
The maps presented allow an analysis of tourism with details of its main attributes, which shows the potential of this tool and this tourist segment, consciously planned, properly structured, can influence the economy of the city.

Although this research has focused only on the attractive (farms) and its services, there is the possibility of further consideration, especially in flows of its activities, whether through trade of goods, logistics, or even your potential visitor, emitting nucleus. Information is essential to control the preservation of their potential and thereby support the development of cartography and tourist tourism planning.

Understanding the complexities of planning and proposing sustainable alternatives for an integrated development of the practices of a community tourism, can be understood as an objective of the research extension. Thus, this study was proposed to contribute to an analysis of a territory with rural characteristics, ready to move in the segment of rural tourism. Strategies such as the use of GIS tools in different areas, which the city of Joinville, through SIMGEO has done, can help create a model of public management and be adapted to different municipalities, according their local reality.

\section{THANKS}

We thank the Ministry of Education of the Brazilian Federal Government that funded this research through the granting of scholarships CAPES.

\section{REFERENCES}

ANDRADE , J. B. de. Fotogrametria. Curitiba: SBEE, 1995.

BENI, M. C. Análise estrutural do turismo. 11 ed. São Paulo: SENAC, 2006.

BIO, S. R. Sistemas de informação: um enfoque gerencial. 2. Ed. São Paulo: Editora ATLAS S.A, 2008.

CARLOS, A. F. A. O turismo e a produção do não-lugar. In: YÁZIGI, E.; CARLOS, A. F. A.; CRUZ, R. C. A. (orgs.). Turismo: Espaço, paisagem e cultura. São Paulo: Editora Hucitec, 1996. 
CASTRO, I. E. et al (Orgs). Geografia: conceitos e temas. Rio de Janeiro: Bertrand Brasil, 2003.

CAZZELLA, A. A. Base de serviços rurais estratégicos à promoção do desenvolvimento territorial no Brasil: uma análise prospectiva. XLV Congresso da Sociedade Brasileira de Economia, Administração e Sociologia Rural - SOBER, Londrina- PR - Julho de 2007.

CLAVAL, P. Geografia cultural: o estado da arte. In: ROSENDAHL, Z.; CORRÊA, R. L. Manifestações da cultura no espaço. Rio de Janeiro: EDUERJ, 1999.

CORRÊA, R. L. et al. Geografia: conceitos e temas. Rio de Janeiro: Bertrand Brasil, 1995.

CORIOLANO, L. N. M. T. O turismo e a relação sociedade-natureza: realidades, conflitos e resistências. Fortaleza: EdUECE, 2007.

- (Org.). Arranjos produtivos locais do turismo comunitário: atores e cenários em mudanças. Fortaleza: EdUECE, 2009.

CRUZ, R. C. A. Planejamento governamental do turismo: convergência e contradições na produção do espaço. In: RODRIGUES, A. B. Turismo e territorialidades plurais: lógicas excludentes ou solidariedade organizacional, 2006.

Geografia do turismo: de lugares a pseudo-lugares. São Paulo: Roca, 2007.

ENGECORPS - CORPO DE ENGENHEIROS CONSULTORES LTDA. 1022-PMJPMS-RT-P003. Abril/2010. Rev. 1.

ESPADAFOR, C. M. L. et al. El catastro em La docência de lãs ciências sociales y jurídicas: uma propuesta interdisciplinar de postgrado. Anais do Congreso Internacional sobre Catrasto Unificado Multipropósito - CICUM. Universidade de Jaén, 2010.

EPAGRI/CIRAM. Base cartográfica digital microbacia rio Piraí. Disponível em: http://ciram.epagri.sc.gov.br. Acesso em 16 de jan de 2013. 
FALKNER, E; MORGAN, D. Aerial mapping: methods and applications. Lewis Publishers is an imprint of CRC Press LLC, 2002.

DUQUE, R. C; MENDES, C. L. O planejamento turístico e a cartografia. Campinas: Alínea, 2006.

FUNDAÇÃO INSTITUTO DE PESQUISA E PLANEJAMENTO PARA O DESENVOLVIMENTO SUSTENTÁVEL DE JOINVILLE - IPPUJ. Disponível em: < http://www.ippuj.sc.gov.br/>. Acesso em 08 de Agosto de 2012. Joinville: Cidade em dados 2009. Caderno. Joinville, PMJ, 2009. 164 p. . Joinville: Cidade em dados 2010/2011. Caderno. Joinville, PMJ, 2011, 194p.

HAESBAERT, R. Território e multiterritorialidade: um debate. In: Revista GEOgraphia. Ano IX, n. 17, 2007.

INSTITUTO BRASILEIRO DE GEOGRAFIA E ESTATÍSTICO (BASE CARTOGRÁFICA 2008). Município de Joinville. Disponível em: $<$ http:||www.ibge.gov.br>. Acesso em: 29 de Nov de 2012.

LEITE, S. P; BONNAL, P. Análise comparada de políticas agrícolas: uma agenda em transformação. Rio de Janeiro: Mauad X, 2011.

LOCH, C.; KIRCHNER, F. F. Cadastro: a base do planejamento regional. In: Encontro Brasileiro de Economia Florestal, I. Anais. Curitiba, 1988. EMBRAPA-CNPF, v. 2, p. 294-306.

MATIAS, L. F. Sistema de Informações Geográficas (SIGCSR) - características e potencialidades. Brasília: CSR/IBAMA, 1996, 33p.

PIRES, P. dos S. et al. Estruturação de matriz de impactos do turismo: o caso do agroturismo no município de Santa Rosa de Lima/SC. Revista Brasileira de Pesquisa em Turismo v. 3, n. 1, p. 68-89, abril 2009. 
PLANO DE FORTALECIMENTO DA GESTÃO PÚBLICA DO TURISMO. CONTREI CONSULTORIA E TREINAMENTO LTDA. Joinville, 2008.

PECQUEUR, B. Territoire, territorialite et developpement. In: Coloque Industrie et Territoire, IREPD, Grenoble, 20-22 octobre 1992.

PORTUGUEZ, A. P. Agroturismo e desenvolvimento regional. São Paulo: HUCITEC, 2002.

RAMOS, C. S. Visualização cartográfica e cartografia multimídia: Conceitos e tecnologias. São Paulo: Unesp, 2005.

RECH, C. M. B. Avaliação do potencial turístico no espaço rural do município de Camboriú-SC: uma abordagem para o planejamento turístico local sob a ótica do cadastro técnico multifinalitário e análise da paisagem. Florianópolis, 2009. Tese de Doutorado em Cadastro Técnico Multifinalitário e Gestão Territorial, Universidade Federal de Santa Catarina.

RODRIGUES, A. B.; (org.). Turismo e geografia: reflexões teóricas e enfoques regionais. São Paulo: Hucitec, 1996.

Turismo e ambiente: reflexões e propostas. 2 ed. São Paulo: Hucitec, 1999.

Turismo e territorialidades plurais - lógicas excludentes ou solidariedade organizacional. Enpublicación: América Latina: cidade, campo e turismo. AmaliaInés Geraiges de Lemos, Mónica Arroyo, María Laura Silveira. CLACSO, Consejo Latino americano de Ciências Sociales, San Pablo. Diciembre, 2006.

SIMGEO - Sistema de Informações Municipais Georreferrenciadas. Disponível em: www.joinville.sc.gov.br. Acesso em 15 de jan de 2013.

ZIMMERMANN, A. planejamento e organização do turismo rural no Brasil. In: ALMEIDA, J. A; FROEHLICH, J. M.; RIEDL, M. (orgs.). Turismo rural e desenvolvimento sustentável. 3 ed. Campinas, SP: Papirus, 2003. p. 127-142. 